\title{
PENATAAN ESTETIKA PERMUKIMAN KUMUH PERKOTAAN BERBASIS PENATAAN FASAD BANGUNAN STUDI KASUS: JALAN INSPEKSI KANAL, MARICAYA BARU KEC. MAKASSAR KOTA MAKASSAR
}

\author{
Armi Indrayuni \\ Dosen Teknik Arsitektur, Universitas Pepabri Makassar \\ uniqlly@yahoo.co.id
}

\begin{abstract}
ABSTRAK
Tingginya tingkat pertumbuhan permukiman kumuh khususnya di Kota Makassar merupakan masalah tersendiri bagi kehidupan kota. Mempengaruhi secara tidak langsung berbagai aspek ekonomi, kesehatan, keamanan dan keindahan yang ditimbulkan dari permukiman dan masyarakat yang tinggal di permukiman kumuh. Penataan estetika permukiman kumuh di lakukan untuk menghilangkan citra kekumuhan demi terciptanya sebuah kota baru yang menuju kota dunia dengan melibatkan berbagai sektor pemerintah, swasta dan masyarakat. Tulisan ini bersifat deskriptif, data dikumpulkan melalui observasi dan wawancara terhadap masyarakat yang bermukim di permukiman kumuh, dilakukan pada permukiman kumuh sepanjang jalan inspeksi kanal dari Pasar Pabaeng-Baeng hingga jalan Pelita. Hasil pengamatan menunjukkan bahwa penataan estetika permukiman kumuh membutuhkan penataan desain sederhana sehingga mudah diterapkan diantaranya penataan keteraturan bangunan, permainan warna pada bangunan dan penggunaan material yang tepat guna. Di perlukan pula pendekatan sosial, ekonomi dan politik secara personal karena tingkat kepekaan masyarakat khususnya tingat bawah sangat rentan dan sensitivitas tinggi.

Keberadaan mereka untuk dihargai dan diakui tinggal di kota sebagai masyarakat "berguna" membutuhkan perhatian khusus dari berbagai sektor khususnya pemerintah. Dibutuhkan pemberdayaan ekonomi yang kreatif guna meningkatkan kesejahteraan dan keberadaan permukiman kumuh yang lebih berestetika sehingga dapat digunakan sebagai aset, daya tarik dan ciri khas Kota Makassar.
\end{abstract}

Kata kunci : Permukiman, Kumuh, Estetika, Makassar

\section{PENDAHULUAN}

\section{Permukiman Kumuh}

Meluasnya lingkungan permukiman kumuh diperkotaan membawa banyak konsekwensi pada kehidupan di perkotaan. Secara estetika konsekwensinya adalah menimbulkan lingkungan yang rendah kualitasnya. Namun lebih dari itu, pemukiman kumuh ini mengakibatkan konflik ruang, kawasan hunian yang sesak dengan daya dukung rendah, menurunnya tingkat kesehatan masyarakat, menurunnya kualitas pelayanan prasarana dan sarana permukiman.

Belum lagi karena kepadatannya, dapat meningkatkan kerawanan dan konflik sosial. Oleh karena itu, permukiman kumuh di perkotaan ini harus segera ditangani agar dampak buruk tidak semakin bertambah (Noegroho, 2010).

Berdasarkan UU No. 1 Tahun 2011 tentang Perumahan dan Kawasan Permukiman, permukiman kumuh adalah permukiman yang tidak layak huni karena ketidakteraturan bangunan, tingkat kepadatan bangunan yang tinggi, dan kualitas bangunan serta sarana dan prasarana yang tidak memenuhi syarat.

Tingginya tingkat urbanisasi dan imigrasi masyarakat dari desa ke kota mengakibatkan terjadinya peningkatan jumlah penduduk di daerah perkotaan, baik secara legal maupun ilegal. Peningkatan jumlah penduduk akan berakibat pula pada kebutuhan akan permukiman.

Dalam upaya pemenuhan kebutuhan tempat tinggal, kaum migran seringkali menyewa rumah di bagian pusat kota yang dekat dengan lokasi mata pencaharian. Akibatnya, terjadi proses pemadatan bangunan yang tidak terkendali dan menciptakan permukiman kumuh atau slums (Priyatno, 2016).

Sebagian yang lain membuat bangunan sendiri dan material seadanya pada bagianbagian tertentu yang dianggap tidak ada status hukum atas tanah sehingga berdampak pada munculnya permukiman liar (squatter settlement). Kumuh sampai saat ini dianggap sebagai fenomena kondisi 'current living space being' yang diterjemahkan sebagai korban 
pasif pembangunan sehingga harus dipisahkan dalam sistem hidup keruangan (Annisa, 2018)

Kumuh adalah kesan atau gambaran secara umum tentang sikap dan tingkah laku yang rendah dilihat dari standar hidup dan penghasilan kelas menengah. Dengan kata lain, kumuh dapat diartikan sebagai tanda atau cap yang diberikan golongan atas yang sudah mapan kepada kumuh dapat ditempatkan sebagai sebab dan dapat pula ditempatkan sebagai akibat. Ditempatkan di mana pun juga, kata kumuh tetap menjurus pada sesuatu hal yang bersifat negatif (Clinard dalam Budiharjo, 1984).

Pemahaman kumuh dapat ditinjau dari :

\section{a. Sebab Kumuh}

Kumuh adalah kemunduran atau kerusakan lingkungan hidup dilihat dari (1) segi fisik, yaitu gangguan yang ditimbulkan oleh unsur-unsur alam seperti air dan udara, (2) segi masyarakat/ sosial, yaitu gangguan yang ditimbulkan oleh manusia sendiri seperti kepadatan lalu lintas, sampah.

b. Akibat Kumuh

Kumuh adalah akibat perkembangan dari gejala-gejala antara lain (1) kondisi perumahan yang buruk; (2) penduduk yang terlalu padat; (3) fasilitas lingkungan yang kurang memadai; (4) tingkah laku menyimpang; (5) budaya kumuh; (6) apati dan isolasi

\section{Estetika Fasad}

Akar kata "fasade" (facade) diambil dari kata Latin "facies" yang merupakan sinonim kata "face" (wajah) dan "appearance" (penampilan). Fasade adalah bagian muka utama eksterior bangunan, berada pada salah satu sisi utama yang biasanya menghadap ke jalan. Fasad utama biasanya adalah sisi bangunan yang mempunyai entrance/pintu masuk utama dan mempunyai karakter detail yang stylistic (Krier, 1996:122).

Fasad menjadi elemen arsitektur terpenting yang mampu menyuarakan fungsi dan makna sebuah bangunan (Krier, 1988: 122). Identitas bangunan lebih mudah diidentifikasi melalui fasadnya. Fasad menyampaikan keadaan budaya saat bangunan itu dibangun; fasad mengungkap kriteria tatanan dan penataan, dan berjasa memberikan kemungkinan dan kreativitas dalam ornamentasi dan dekorasi. Suatu fasad juga menceritakan hal-ihwal penghuni suatu gedung, memberikan semacam identitas kolektif sebagai suatu komunitas itu dalam publik (Burden, 1995:32).

Menurut Ching (1985), tampilan fasad bangunan dipengaruhi oleh wujud, dimensi, warna, tekstur, sedangkan menurut Harani (2011) yang mempengaruhi tampilan fasad bangunan adalah wujud, warna dan dimensi.

Fenomena permasalahan visual kawasan perkotaan merupakan akibat dari konflik berbagai kepentingan, kemampuan maupun persepsi yang heterogen dari warga kota yang tercermin pada kondisi fisik perkotaan yang menimbulkan komposisi visual/wajah kota yang sulit dikenal.

Perubahan komposisi visual kota ini lebih diperkuat dengan cepatnya pertumbuhan bangunan yang tidak kontekstual. Perubahan image/citra visual yang terjadi dapat dengan cepat dirasakan sebagai akibat tanggapan visual yang terjadi antara pengamat dengan elemen kawasan tersebut (Lynch, 1960 dalam Firzal, 2002).

Tinjauan visual kawasan merupakan salah satu upaya untuk memberikan kontrol dan arahan karakter kawasan sebagai pengarah pergerakan, orientasi, penandaan kota yang sesuai dengan karakter kawasan tersebut (Kristiadi dalam Firzal, 2002).

\section{Peraturan Permukiman Kumuh}

Menurut peraturan pemerintah No 14 tahun 2016 permukiman kumuh adalah permukiman yang tidak layak huni karena ketidakteraturan bangunan, tingkat kepadatan bangunan yang tinggi, dan kualitas bangunan serta sarana dan prasarana yang tidak memenuhi syarat.

Adapun kriteria kondisi kekumuhan yang ditinjau dari: bangunan gedung, jalan lingkungan, penyediaan air minum, drainase lingkungan, pengelolaan air limbah, pengelolaan persampahan; dan/atau, proteksi kebakaran.

Kriteria kekumuhan ditinjau dari bangunan gedung mencakup: ketidakteraturan bangunan, tingkat kepadatan bangunan tinggi yang tidak sesuai, dengan rencana tata ruang; dan/atau, kualitas bangunan yang tidak memenuhi syarat.

\section{METODE}

Penelitian ini mengidentifikasi karakteristik permukiman kumuh yang menggunakan 
metode kuantitatif deskriptif dengan mengacu pada kriteria kekumuhan berdasarkan Peraturan Menteri Pekerjaan Umum Nomor 02 Tahun 2016 tentang Peningkatan Kualitas terhadap Perumahan dan Permukiman Kumuh.

Penelitian dilakukan di sepanjang jalan Inspeksi Kanal di kecamatan Makassar. Metode pengumpulan data yang digunakan secara observasi langsung pada objek penelitian dan melalui wawancara dimana pengumpulan informasi melalui tanya jawab kepada pihak yang berhubungan dengan penelitian ini, baik secara langsung maupun tidak langsung.

Data yang telah dikumpulkan selanjutnya di analisis dengan menggunakan analisis deskriptif kualitatif untuk menjawab dan mendapatkan solusi bagi permasalahan yang telah dikemukakan sebelumnya serta memberi usulan pengembangan.

\section{HASIL PENELITIAN}

Pesatnya perkembangan permukiman perkotaan disebabkan oleh pertumbuhan penduduk maupun urbanisasi yang mengakibatkan timbulnya permukiman kumuh. (Solehati, dkk. 2017). Hal ini memicu peningkatan pelayananan dasar perkotaan terhadap kebutuhan hunian. Perumahan dan permukiman menjadi permasalahan di kawasan perkotaan, tidak hanya terkait dengan penyediaan lahan dan harga lahan, tetapi juga permasalahan mewujudkan hunian yang layak bagi masyarakat.

Permasalahan tersebut timbul pada saat tingginya pertumbuhan penduduk perkotaan yang berakibat pada meningkatnya tuntutan akan kebutuhan perumahan, selain itu pemerintah juga tidak memiliki kemampuan finansial yang memadai untuk memenuhi tingginya tuntutan ketersediaan hunian, cadangan lahan yang tersisa di bagian dalam kawasan perkotaan dengan keterbatasan kemampuan dan keterampilan.

Mereka terpaksa hidup di sektor informal dalam skala kecil dan penghasilan rendah dengan memilih tinggal dengan lokasi sepanjang kanal. Permukiman dibangun seadanya dengan material bangunan sisa secara amburadul sesuai luas lahan kosong yang ada.

Menyebabkan timbulnya kesemrawutan bangunan dan visual yang kurang menarik padahal pemerintah telah melakukan pembersihan kanal secara berkesinambungan demi terciptanya lingkungan yang bersih dan nyaman

Kondisi bangunan hunian sepanjang jalan Inspeksi Kanal mencakup tiga kriteria antara lain di dimensi dengan indikator ketidakteraturan bangunan, warna dan wujud/material dalam skala tinggi, sedang dan rendah.

\section{PEMBAHASAN}

Fasad merupakan elemen arsitektur terpenting yang mampu menyuarakan fungsi dan makna sebuah bangunan (Krier dalam Widaningsih, 2004). Sebagai suatu keseluruhan, fasad tersusun dari elemen tunggal, suatu kesatuan tersendiri dengan kemampuan untuk mengekspresikan diri mereka sendiri.

Elemen tersebut yaitu alas, jendela, atap, dan sebagainya karena sifat alaminya merupakan benda-benda yang berbeda sehingga memiliki bentuk, warna dan bahan yang berbeda (Krier dalam Widaningsih, 2004).

Ching dalam Widaningsih (2004) mengatakan bahwa: "Komponen visual yang menjadi objek transformasi dan modifikasi dari fasad bangunan dapat diamati dengan membuat klasifikasi melalui prinsip-prinsip gagasan formatif yang menekankan pada geometri, simetri, kontras, ritme,

proporsi dan skala".

Menurut Ching (1979) "Perlengkapan visual bentuk yang menjadi objek transformasi dan modifikasi bentuk elemen pada fasad bangunan meliputi sosok, ukuran, warna, tekstur, posisi, orientasi dan inersia visual."Suatu dasar geometris untuk mengorganisir bentuk dan ruang dalam sebuah bangunan. Prinsip-prinsip tambahan yang bisa digunakan untuk menciptakan tatanan di dalam suatu komposisi arsitektural (Ching, 2008).

\section{Ketidakteraturan Bangunan}

Berdasarkan hasil penelitian didapatkan $87 \%$ ketidakteraturan bangunan dalam kriteria fasad skala tinggi dan $13 \%$ skala sedang. Hal ini disebabkan karena rumah yang dibangun secara temporer sekaligus di fungsikan sebagai lahan komersil seperti warung, bengkel dan sebagainya. Sehingga menimbulkan kesemrawutan, letak dan ukuran pintu serta jendela seadanya. 
Fasad merupakan wajah suatu bangunan yang pertama kali terlihat oleh publik, merupakan gambaran bangunan seluruhnya, bahkan tak jarang setelah melihatnya kemudian akan mencermati meskipun hanya dalam waktu sesaat sebelum memasuki bangunan tersebut.

Walaupun termasuk permukiman kumuh, masyarakat yang tinggal didalam kawasan tersebut juga mengharapkan adanya nilai estetika yang baik sehingga terdapat kenyamanan untuk tinggal didalamnya. Fasad sebagai point of interest dan dapat merepresentasikan karakteristik estetika.

Hal -hal yang perlu diperhatikan dalam mendesain elemen fasad adalah gunakan standarisasi yang berhubungan dengan kesehatan, keselamatan, keamanan dan kenyamanan pengguna. Agar fungsi bangunan berjalan maksimal, sesuaikan ukuran masing masing elemen fasad terhadap standar yang ada sehingga dihasilkan fasad estetis.

\section{Warna Bangunan}

Adapun penggunaan warna pada bangunan khususnya fasad. Ditemukan 65\% bangunan tanpa warna atau pengecatan dan $16 \%$ dengan warna bangunan yang sudah kusam serta $16 \%$ dengan kondisi warna baik. Hal ini disebabkan karena ketidakmampuan untuk finishing bangunan dan ketidakpedulian serta ketidaktahuan masyarakat akan keindahan atau estetika bangunan.

Penggunaan warna pada bangunan mampu menghasilkan kenyaman psikologis tersendiri, bukanlah sekadar elemen dasar desain, sebab warna juga memiliki fungsi dan makna. Lebih dari sekadar estetika, warna juga mampu memengaruhi suasana hati sang penghuni.

\section{Fungsi Warna}

\section{Estetika}

Hal sederhana dari fungsi warna dalam suatu ruangan adalah memberikan nilai estetika, keindahan, serta menghilangkan kesan kusam dan tidak terawat. Suatu ruangan yang didesain dengan menggunakan warna-warna tertentu, akan terlihat jauh lebih indah daripada sebuah ruangan yang tidak dicat

Manipulasi

Mengaplikasikan cat warna yang tepat pada eksterior/interior hunian merupakan salah satu cara untuk "manipulasi" ruangan. Manipulasi yang dimaksud adalah kesan yang dihadirkan dari warna yang diterapkan pada bangunan. Penggunaan warna tertentu seperti putih untuk menciptakan kesan luas dan lapang dalam sebuah ruangan sempit. Demikian sebaliknya, warna juga mampu memanipulasi ruangan yang terlalu luas agar nampak lebih berisi.

\section{Psikologis}

Penggunaan warna merupakan fokus utama dalam mendesain. Setiap warna juga memiliki potensi yang memberikan efek positif serta negatif pada seseorang. Penggunaan warna berkaitan dengan kondisi psikologis seseorang yang akan memengaruhi tubuh, pikiran, emosi dan keseimbangan ketiganya pada diri manusia.

Seperti yang dilakukan di kota di Malang daerah salah satunya di Kelurahan Jodipan, Kecamatan Blimbing. Kampung ini terletak di bantaran sungai Brantas, yang juga terletak dibawah jembatan rel kereta api. Letak kampung ini di sebelah selatan stasiun kota baru Kota Malang.

Adapun permasalahan yang terjadi di kampung Jodipan antara lain: satu, Kampung Jodipan merupakan kampung dengan kepadatan penduduk yang tinggi. Bisa dilihat berdasarkan BAPPEDA kampung Jodipan memiliki luas wilayah seluas 49 ha dengan jumlah penduduk 13.201 jiwa. Kampung ini pun dapat berubah menjadi "warna warni" dan mampu menjadi objek wisata di kotanya.

Demikian juga yang dilakukan di beberapa negara maju dalam menyelesaikan permukiman kumuh, menggunakan konsep tanpa menggusur, memainkan teknik desain visualisasi dan konsep warna warni.

Warna menjadi tolok ukur pertama visual sebuah bangunan. Warna dapat menjadikan sarana ekspresi diri melalui visual bangunan. Warna menjadi property visual yang melekat pada semua bentuk. Warna - warna yang kita sebut ke obyek bersumber pada cahaya yang menerangi dan mengungkapkan bentuk dan ruang.

Kesan yang ditimbulkan dari warna terang akan mengesankan ruangan terasa luas. Sementara kesan yang ditimbulkan dari warna gelap akan memberi kesan sempit dan tertekan. Dari pernyataan tersebut diketahui bahwa warna berperan penting dalam ruang. Untuk permukiman kumuh sendiri dibutuhkan warna terang yang diharapkan mampu member kesan luas dan lapang. 


\section{Material Bangunan}

Penggunaan material bangunan rumah yang tidak sesuai fungsinya diperoleh sebesar $42 \%$ dan yang sudah sesuai sebesar $58 \%$. Penggunaan bahan seng sebagai dinding atau tembok rumah karena lebih menghemat biaya pembangunan walaupun dampak ketidaknyamanan yang ditimbulkan bagi penghuni rumah seperti panas dan dingin yang tidak mampu di serap oleh material seng.

Penyelesain penataan bangunan diatas dapat dilakukan dengan penataan desain simpel dan umum dengan kesatuan warna pada permukiman sehingga penggunaan material yang tidak tepat dan merusak visual dapat di minimalisir.

\section{Dinding Bangunan}

Pada permukiman kumuh sepanjang jalan inspeksi kanal masih bangyak menggunakan material seng sebagai tembok padahal dari segi struktural tidak mampu dijadikan sebagai dinding.

Dinding adalah suatu struktur padat yang membatasi dan kadang melindungi suatu area. Umumnya, dinding membatasi suatu bangunan dan menyokong struktur lainnya, membatasi ruang dalam bangunan menjadi ruanganruangan, atau melindungi atau membatasi suatu ruang di alam terbuka.

Tiga jenis utama dinding struktural adalah dinding bangunan, dinding pembatas (boundary), serta dinding penahan (retaining). Dinding bangunan memiliki dua fungsi utama, yaitu menyokong atap dan langit-langit, membagi ruangan, serta melindungi terhadap intrusi dan cuaca.

Dinding pembatas mencakup dinding privasi, dinding penanda batas, serta dinding kota. Dinding penahan berfungsi sebagai penghadang gerakan tanah, batuan, atau air dan dapat berupa bagian eksternal ataupun internal suatu bangunan.

\section{Jenis dinding}

Dinding Partisi: Dinding ringan yang memisahkan antar ruang dalam. Terbuat dari gypsum, fiber, tripleks atau Duplex

Dinding Pembatas: Untuk menandakan batas lahan. Atau bisa disebut dinding Privasi
Dinding Penahan: Digunakan pada tanah yang berkontur dan dibutuhkan struktur tambahan untuk menahan tekanan tanah.

Dinding Struktural: Untuk menopang atap dan sama sekali tidak menggunakan cor beton untuk kolom. Konstruksinya 100\% mengandalkan pasangan batubata dan semen

Dinding Non-Struktural: Dinding yang tidak menopang beban, hanya sebagai pembatas apabila dinding di robohkan, maka bangunan tetap berdiri. beberapa material dinding nonstruktural diantaranya seperti batu bata, batako, bata ringan, kayu dan kaca.

\section{KESIMPULAN}

Berdasarkan hasil penelitian dapat disimpulkan bahwa permukiman kumuh dapat di ubah menjadi permukiman layak huni dengan penataan sebagai berikut : menggunakan penataan desain warna fasad yang seragam maupun bervariasi sehingga masalah ketidakteraturan bangunan dalam hal fasad bangunan, kekurangan warna dan ketidaksesuaian material bangunan dapat di minimalisir. Warna serta material yang digunakan memiliki pola yang selaras dan tidak jauh berbeda.

Estetika visualisasi bangunan pun dapat diperoleh tentunya melibatkan semua kerjasama semua pihak dari pemerintah, pihak swasta, akademisi dan kesadaran masyarakat sendiri.

\section{LAMPIRAN}

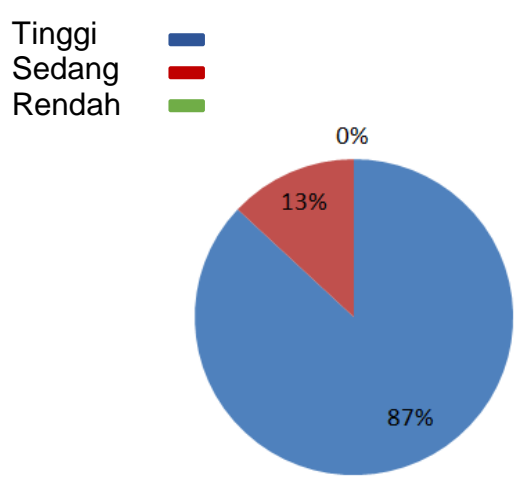

(Sumber: Analisa Peneliti, 2018)

Gambar 1. Persentase Ketidakteraturan Bangunan

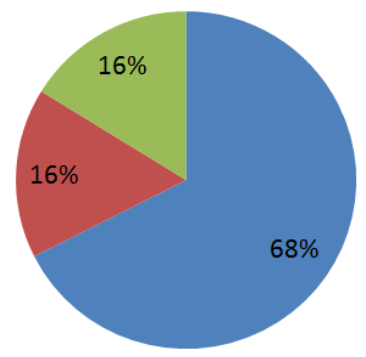


(Sumber: Analisa Peneliti, 2018)

Gambar 2. Persentase Warna Bangunan

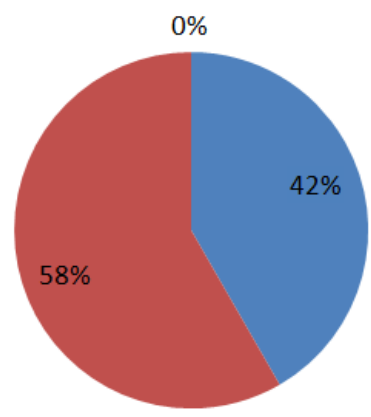

(Sumber: Analisa Peneliti, 2018)

Gambar 3. Persentase Kesesuaian Material Bangunan

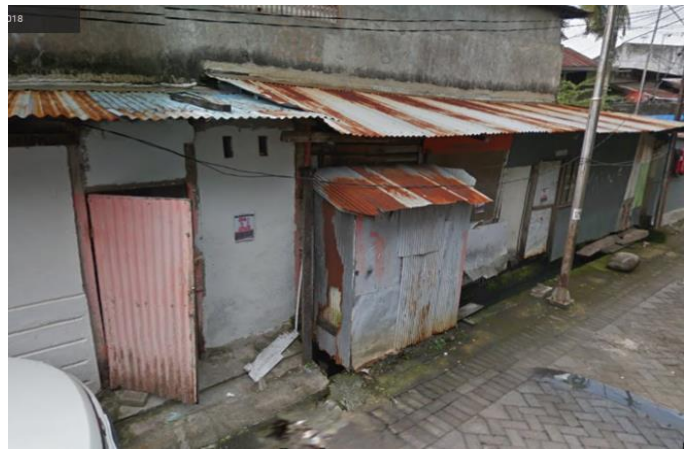

(Sumber: Analisa Peneliti, 2018)

Gambar 4. Ketidakteraturan Bangunan

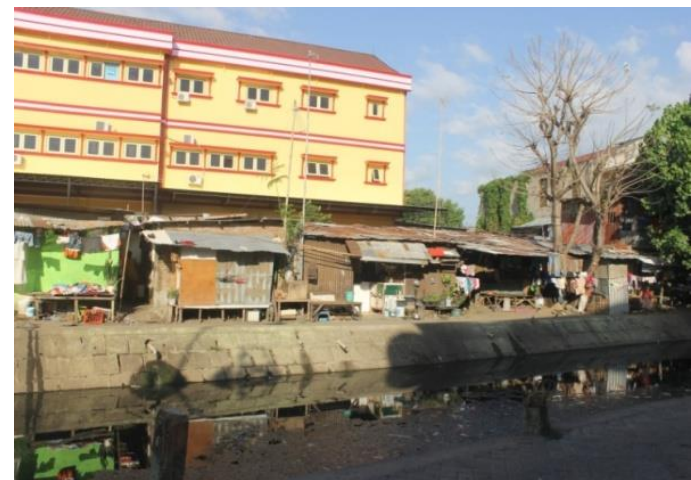

(Sumber: Analisa Peneliti, 2018) Gambar 5. Bangunan Tanpa Warna

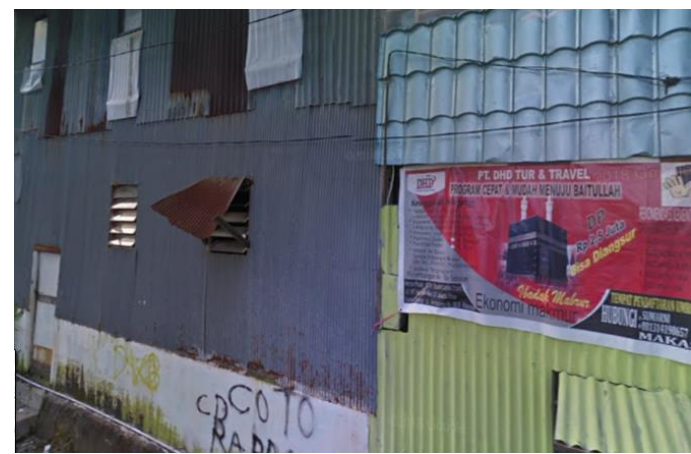

(Sumber: Analisa Peneliti, 2018)

Gambar 6. Ketidaksesuaian Penggunaan Material Bangunan

\section{DAFTAR PUSTAKA}

Annisa, A. 2018. Karakteristik Hunian Permukiman Kumuh Kampung Sapiria Kelurahan Lembo Kota Makassar. National Academic Journal Architecture, Volume 5, Nomor 1, 2018, hlm 13-22 p-ISSN: 2302 - 6073, e-ISSN: 2579 - 4809. Makassar

Burden, Ernest. 1995. Element of Architectural Design: a visual resource. Van Nostrand Reinhold. New York, N.Y.

Ching, F. D. K. (1985). Arsitektur: Bentuk-Ruang \&Susunannya. Jakarta: Erlangga.

Harani, A. R. (2011). Pengaruh Tampilan Bangunan Terhadap Serial Vision pada Koridor Jalan Pemuda Semarang. Universitas Diponegoro.

Firzal, Yohanes. 2002. Arahan Rancangan Menjaga Karakter Visual Kawasan. Tesis Arsitektur S2 Universitas Gadjah Mada. Yogyakarta

Krier, Rob. (2001). Komposisi Arsitektur. Erlangga. Jakarta London

Krier, Rob. 1983. Elements of Architecture. Architecture Design AD Publications Ltd,

Noegroho, N. 2010. Penataan Perumahan Kumuh Di Perkotaan Berbasis Kawasan. Jurnal ComTech Vol.1 No.2 Desember 2010: 1033-1040, Jakarta Barat.

Undang-Undang Nomor 1 Tahun 2011 Tentang "Perumahan dan Kawasan Permukiman". (2011). Jakarta. 
Widaningsih, Lilis (2004). Karakteristik Fasade Bangunan Factory Outlet Di Jalan Ir. H.Djuanda Bandung. Jurusan Teknik Arsitektur. Fakultas Teknik. Universitas Pendidikan Indonesia. Bandung 